\title{
TIPS
}

\section{We're in the Money: A Guide to Getting Involved in Student Financial Literacy for Business Librarians}

\author{
LAUREN REITER \\ The Pennsylvania State University, University Park \\ Imr29@psu.edu
}

\begin{abstract}
Column Introduction Many of us in business librarianship have the opportunity to contribute to financial literary programming, knowledge, and education with our constituents in academia. With the increase in entrepreneurial endeavors at various universities, it is important to help students understand the need for financial planning, budgeting, and other important concepts within financial literacy. In this article, Lauren Reiter discusses some tips on how business librarians can connect with students and other campus stakeholders in the hopes of forwarding financial literacy efforts, and points to additional helpful resources to consider as well. - Ryan Splenda and Eve Wider, Column Editors
\end{abstract}

Academic libraries are increasingly taking part in financial literacy initiatives on campus, based on the abundance of recent examples and case studies in the professional literature (Dawes, 2013; Jagman et al., 2014; Roggenkamp, 2014; Gil, 2015; Reiter, 2015; Doucette, 2017; Woodward and Timm, 2015; Mross and Reiter, 2019b; Mross, 2019). As a business librarian, you may find yourself wanting (or being asked) to join these efforts for a number of reasons. You may want to use your own comfort and familiarity with the key terms and concepts of financial literacy to help students, or you may want to ensure entrepreneurs have the personal finance habits needed to get their businesses off the ground. Or you may have noticed a lack of personal finance classes in the curriculum. You may have been asked to collaborate by campus partners, or you may have been asked when a library administrator heard the word "financial" or the business school heard the word "literacy." You may be concerned about education debt and college affordability. Or you may have your own pile of student loan debt and want to help students understand their options. Whatever your reason for getting involved, a business librarian will have no trouble delivering an array of financial literacy-related services using the tips, examples, and resources described below.

\section{Identify Financial Literacy Needs and Partners}

Conducting an environmental scan and getting to know the needs of your community is a best practice and an important first step when developing library financial literacy programs and services (Mross and Reiter, 2019a). Start with the questions you would like to answer, such as "Are students worried about money?," "What are their biggest financial concerns?," "Does the university offer any personal finance courses?," and "Are there other campus units already providing financial literacy programs and services?"

Next, consider the available information sources. Surveys can be useful tools for gathering opinions and perspectives but it is not always feasible to develop and deploy them on your own. National surveys, such as the National Financial Capability Study from FINRA Investor Education Foundation and Study on 
Collegiate Financial Wellness from Ohio State, can offer a broad view of trends in student financial literacy. You may also find insights from surveys conducted at your institution, even if they do not directly focus on money or personal finance. For example, Mross noticed that a survey of international students at her institution showed finances to be the third-highest concern of this population (2019). With knowledge of a specific audience and their needs, Mross developed an English conversation group session that used television show clips to jumpstart discussions about money and paved the way for more financial literacy programs and services at her library.

In addition to identifying pain points, environmental scanning can assist in the discovery of potential partners. A vast number of campus units potentially have a stake in financial literacy. Some universities have dedicated money management, financial literacy, or wellness centers that focus on student financial education. Other campus participants in financial literacy may include financial aid, student services, student life, bursar, career development, health services, student government, or the business school and other academic departments. With an awareness of stakeholders across campus, the business librarian can consider what types of support from the library would best complement and-advance existing initiatives and support partners. The librarian can even take a leading role, as demonstrated by Gil, who formed a committee with participants from across the university and initiated Money Smart Week programming at her institution (2015).

\section{Consider Your Options}

From fielding personal finance questions at the reference desk to hosting personal finance book clubs, the variety of ways in which libraries are participating in financial literacy is impressive. Some approaches place great demands on the librarian's time and other scarce resources, while others have fewer barriers. Studies of both academic and public libraries have identified lack of time as a major challenge to developing financial literacy support (Smith and Eschenfelder, 2013; Reiter and Ford, 2019). With this in mind, it is important to consider the different possibilities for mixing and matching to best meet local needs for financial literacy support and avoid trying to do it all.

Highlight Personal Finance Books and Websites. A major reason that libraries of all types get involved with financial literacy is because libraries have an established reputation as providers of highquality, objective, trustworthy information sources, which are critical for financial decision-making. Acquiring personal finance books is usually already in a business librarian's collection development workflow. Intentionally drawing more attention to these resources is a low-barrier approach to making a meaningful contribution to student financial literacy. Make your selections after considering the findings of your environmental scan and create a book display to highlight helpful, topical resources. For maximum impact, book displays can be tied to campus events or recognized dates, such as Financial Literacy Month or Money Smart Week @ your library. Keep in mind that books in the personal finance genre can vary greatly in the guidance offered and even how they define their end goal of financial literacy, ranging from most basic solvency to financial independence (Faulkner, 2017). For inspiration, ALA offers an online guide for building financial literacy collections, Financial Literacy in Public Libraries: $A$ Guide for Building Collections (see Recommended Resources). While tailored for public libraries, the resource suggests books on banking, budgeting, credit and debt, financing college, identity theft, investing, saving and spending, and teen finance that may be useful in a college and university setting. Smart investing @ your library from ALA and the FINRA Investor Education Foundation also provides collection management tools and guidelines for personal finance and investing materials. 
In addition to books, online financial information and education resources are abundant and accessible but a simple search for "interest rates" yields results from news organizations, commercial entities, banks, government agencies, non-profits, universities, and more. The cacophony of advice from these different sources can be overwhelming, time-intensive, and frustrating to sift through, and websites touting financial education may have additional objectives, such as their own financial gain. To guide users to the most reputable financial tools and resources online, many academic libraries have curated online financial literacy and personal finance guides (LibGuides), such as Michigan State (Michigan State University Libraries, 2020), Illinois (University of Illinois Library, 2018), Georgetown (Georgetown University Library, 2019) and Dartmouth (Dartmouth Library, 2019). These guides highlight free websites and online courses, such as Paying for College from the Consumer Financial Protection Bureau and Smart about Money from the National Endowment for Financial Education, that cover resources and tools that align with common financial questions of college students. The online library guides also present an opportunity to showcase library subscription databases with financial education components, such as Morningstar and Standard \& Poor's NetAdvantage, and important campus resources such as financial literacy centers, wellness programs, financial aid offices, food pantries, and career services offices.

Host a Program. Offering programs is another popular way for libraries to lend their support to student financial literacy. A librarian with strong personal finance expertise may feel comfortable leading a session; however, it is more common to invite financial educators and licensed financial professionals to the library. For example, the Money Talks series at University of Maryland library features facilitators from the faculty and local non-profit organizations (University of Maryland University Libraries, 2020). Other campus and community partners may also be available to offer their expertise, including money management centers, financial aid offices, cooperative extension, banks, credit unions, insurance agents, government agencies, and community organizations. Librarians may hesitate to offer any type of financial literacy support due to fear of being held liable for any financial, investment, or tax advice inadvertently provided (Smith and Eschenfelder, 2013; Faulkner, 2017). This concern is magnified when outside individuals are given a platform to speak at financial literacy programs. Prior to a session, it is important to clarify to the presenter that the program's purpose is to educate rather than advise attendees, and it is certainly not an opportunity to sell or earn profit from the captive audience. The Consumer Financial Protection Bureau developed the Community Partnership Guidebook for Libraries, which walks through partnering with outside organizations, including finding and vetting partners, and setting up formal agreements.

Another key concern when planning a financial literacy program is attendance. While most financial educators believe that connecting with just one individual is a valuable chance to make a difference in a student's financial life, the process of coordinating with presenters, setting dates, booking rooms, designing marketing materials, promoting events, and ordering refreshments is an incredible investment of time and resources; it can be discouraging to have low attendance at a program. To promote better attendance, consider how to time an event to match the rhythm of the semester and avoid conflicts. During mid-terms and finals, investing and student loans may not be students' most pressing concern. However, in the weeks leading up to spring break, a session about spending without going over budget might spark an interest. Campus partners can also help to promote attendance at sessions, including faculty who might give extra credit to students for participating in co-curricular events, or financial aid officers and academic advisers who encounter students who would benefit from the financial education. For more tips and best practices for library financial literacy programming, look to Financial Education in Libraries: Guidelines and Best Practices for Service from RUSA. 
Plug Into Existing Programs and Services. Financial literacy may not fit into your institution as a stand-alone effort. Libraries and business schools have many high-priority curricular and co-curricular goals and commitments, and it is understandable that financial literacy may not be one of them. If you would still like to try to add a dose of financial literacy, consider whether any of your existing programs and services dovetail with the topic. For example, many universities are highly engaged in entrepreneurship and are looking to the library to support student entrepreneurs. In addition to business research skills and resources, entrepreneurs will need financial management skills and an understanding of how their personal credit history could impact the future of their business. Financial literacy programming can help address this gap. At two Penn State campuses, two librarians offered three financial literacy workshops for entrepreneurs during Startup Week and featured speakers from a credit union and Small Business Development Center at their respective events (Mross and Reiter, 2019b). Two of the workshops were targeted for students in the early stages of developing a business idea or writing a business plan. These sessions covered topics such as financing options, the documentation needed to secure financing, and measures of personal and business credit worthiness. The third workshop focused on sustaining or growing an existing business and provided guidance on ratio analysis and more advanced financial tools. Encouraged by event attendance and positive feedback from participants, Mross and Reiter have plans to identify more opportunities to integrate financial literacy into library support for campus entrepreneurship initiatives.

Another area of focus and indicator of success for many colleges and universities is career development and placement. Many business librarians are active in providing support for career exploration and the job hunt through online guides, one-shot instruction sessions, a workshop series, and reference services (Wood, Howard, and Reiter, 2018). Career preparation support from the library can help students get the job and also support them in decisions that impact their financial future (Albarillo 2016). Geraci, Hickey, and LaVoice describe how librarians can help students find job and salary data, thereby carving out a role for library reference services in the salary negotiation process, a key financial milestone for those on the job market (2016). This example introduces a financial literacy skill at a time of need and action, which may make the student more receptive to learning and the experience more memorable as well. Even if a library cannot offer dedicated financial literacy programming, learning opportunities can still be woven into library services in small, unexpected ways that make a significant impact.

\section{Conclusion}

There are many paths to impactful library financial literacy programs and services, and it can take some experimentation to find the best approach for your community. Whichever direction you choose, your student financial literacy efforts help to support the next generation of informed consumers as they navigate complicated financial questions and develop valuable skills and knowledge for everyday life.

\section{Recommended Resources}

Community Partnership Guidebook for Libraries, Consumer Financial Protection Bureau: https://files.consumerfinance.gov/f/201406_cfpb_partner-guidebook.pdf

Financial Education in Libraries: Guidelines and Best Practices for Service, Reference \& User Services Association: http://www.ala.org/rusa/sites/ala.org.rusa/files/content/FLEGuidelines_Final_September_2014.pdf 
Ticker: The Academic Business Librarianship Review, 5:1 (2020)

https://doi.org/10.3998/ticker.16481003.0005.106

(C)2020 Lauren Reiter

Financial Literacy in Public Libraries: A Guide for Building Collections, American Library Association: http://libguides.ala.org/finra-ore/personalfinance/home

Money Smart Week, American Library Association and Federal Reserve Bank (Chicago): http://www.ala.org/aboutala/offices/money-smart-week

National Financial Capability Study, FINRA Investor Education Foundation: https://www.usfinancialcapability.org/

Paying for College, Consumer Financial Protection Bureau: https://www.consumerfinance.gov/paying-for-college/

Smart About Money, National Endowment for Financial Education: https://www.smartaboutmoney.org/

Smart investing @ your library, American Library Association and FINRA Investor Education Foundation: https://smartinvesting.ala.org/

Study on Collegiate Financial Wellness, The Ohio State University: https://cssl.osu.edu/research-projects/study-oncollegiate-financial-wellness 
Ticker: The Academic Business Librarianship Review, 5:1 (2020)

https://doi.org/10.3998/ticker.16481003.0005.106

(C)2020 Lauren Reiter

\section{References}

Albarillo, F. (2016). Teaching career information literacy in the academic library. In C. Smallwood (Ed.), The Library's Role in Supporting Financial Literacy for Patrons. (pp.189-98). Lantham, MD: Rowman \& Littlefield.

Dartmouth Library. (2019). Library Resources for Personal Finance. https://researchguides.dartmouth.edu/personalfinance

Dawes, T. A. (2013). Libraries, ACRL and financial literacy: Helping students make sound decisions. College \& Research Libraries News, 74(9), 466-467. https://doi.org/10.5860/crln.74.9.9007

Doucette, W.C. (2017). Why our financial literacy programming died (and how yours can succeed), Tennessee Libraries, 67(4). https://www.tnla.org/page/TL67_4_financiallit

Faulkner, A.E. (2017). Financial literacy education in the United States: Exploring popular personal finance literature, Journal of Librarianship and Information Science, 49(3), 287-98. https://doi:10.1177/0961000615616106

Georgetown University Library. (2019.) Business News-Personal Finance. https://guides.library.georgetown.edu/c.php?g=75796\&p=489311

Geraci, A., Hickey, D., \& LaVoice, K. (2016). Getting the patron to "yes": The academic librarian's role in supporting salary negotiations. In C. Smallwood (Ed.), The library's role in supporting financial literacy for patrons (pp.18998). Lantham, MD: Rowman \& Littlefield.

Gil, E. L. (2015). Leading the way for financial literacy education: A case study on collaboration. Journal of Business \& Finance Librarianship, 20(1-2), 27-53. https://doi.org/10.1080/08963568.2015.978710

Jagman, H., Lewis, K., Nunn, B., \& Walter, S. (2014). Financial literacy across the curriculum (and beyond). College \& Research Libraries News, 75(5), 254-257. https://doi.org/10.5860/crln.75.5.9124

Michigan State University Libraries. (2020). Financial literacy. https://libguides.lib.msu.edu/financialliteracy

Mross, E. (2019). Laughing all the way to the bank: Using television clips to promote financial literacy. Ticker: The Academic Business Librarianship Review, 4(1). https://doi.org/10.3998/ticker.16481003.0004.103

Mross, E. \& Reiter, L. (2019a). Building Capital at the Library: Financial Literacy Programming and Partnerships. Pennsy/vania Libraries: Research \& Practice, 7(1), 54-60. https://doi.org/10.5195/palrap.2019.196

Mross, E., \& Reiter, L. (2019b). Partners in financial literacy: Outreach to student entrepreneurs. College \& Research Libraries News, 80(10), 575-579. https://doi.org/10.5860/crln.80.10.575

Reiter, L. (2015). Financial Literacy and the Academic Library: Exploring the Peer-to-Peer Approach. Journal of Business \& Finance Librarianship, 20(1-2), 54-65. https://doi.org/10.1080/08963568.2015.977732

Reiter, L. \& Ford, B. (2019). Library support for student financial literacy: A survey of librarians at large academic institutions. College \& Research Libraries, 80(5), 618-637. https://doi.org/10.5860/crl.80.5.618

Roggenkamp, J. (2014). Financial literacy and community colleges. College \& Research Libraries News, 75(3), 142143. https://doi.org/10.5860/crln.75.3.9089 
Ticker: The Academic Business Librarianship Review, 5:1 (2020)

https://doi.org/10.3998/ticker.16481003.0005.106

(C)2020 Lauren Reiter

Smith, C.A., and Eschenfelder, K.R. (2013). Public libraries in an age of financial complexity: Toward enhancing community financial literacy, The Library Quarterly: Information, Community, Policy, 83(4), 299-320. https://doi.org/10.1086/671912

University of Illinois Library. (2018). Financial literacy. https://guides.library.illinois.edu/financialliteracy

University of Maryland University Libraries. (2020). Money Talks. https://www.lib.umd.edu/rc/money-talks

Wood, N., Howard, H., \& Reiter, L. (2018). Landing the Job: Tips and Tricks to Prepare Students for the Job Hunt. What's Past Is Prologue: Charleston Conference Proceedings 2017. Presented at the Charleston Conference. https://doi.org/10.5703/1288284316677

Woodward, T. \& Timm, S. (2015). Creating Money Smart students: Using Money Smart Week as a platform for outreach in an academic library, Texas Library Journal, 91(4), 9-10. https://txla.org/wp-

content/uploads/2018/09/TLJ-Winter-2015.pdf 